\title{
Identification of Ectoparasites and Endoparasites on Java Langurs \\ (Trachypithecus sp.) and Silvery Gibbons (Hylobates moloch) in The Aspinall Foundation Indonesia Program
}

\author{
${ }^{1)}$ Ghifari Lutfi Fauzi, ${ }^{2)}$ Endang Suprihati ${ }^{D},{ }^{2)}$ Poedji Hastutiek, ${ }^{3)}$ Boedi Setiawan, ${ }^{4}$ Retno \\ Wulansari \\ 1) Student, Faculty of Veterinary Medicine, Universitas Airlangga, ghifarilutfifauzi@gmail.com \\ ${ }^{2)}$ Division of Veterinary Parasitology, Faculty of Veterinary Medicine, Universitas Airlangga \\ 3) Division of Veterinary Clinic, Faculty of Veterinary Medicine, Universitas Airlangga \\ ${ }^{4)}$ Veterinary Internal Medicine Division, Department of Clinic, Reproduction and Pathology, Faculty of \\ Veterinary Medicine, IPB University \\ Corresponding author: esuprihati@yahoo.co.id
}

\begin{abstract}
This study aimed to determine the prevalence rate and to identify parasites (endoparasite and ectoparasite) on Java Langur and Silvery Gibbon, these primates are rehabilitated in The Aspinall Foundation Indonesia Program. This research was conducted from February until October 2020. The fecal examination methods used in this research were native method and ovatec flotation method, while the ectoparasite examination used native method, mounting method, and scraping method. Based on a total of 68 samples examined, the result showed that 10 samples were positive infected by Trichuris trichiura and 2 samples were infested by Pedicinus ancoratus. The conclusion of this study indicated that the prevalence rate of Trichuris trichiura was $21.1 \%$ and Pedicinus ancoratus was $5.3 \%$ on 19 West Java Langurs, the prevalence rate of Trichuris trichiura was 3.3\% and Pedicinus ancoratus was $3.3 \%$ on 30 East Java Langurs, the prevalence rate of Trichuris trichiura was $26.3 \%$ and no infestation of Pedicinus ancoratus was found on 19 Silvery Gibbons.
\end{abstract}

Keywords: Ectoparasite, Endoparasite, Java Langur, Silvery Gibbon, prevalence, primate

\section{Introduction}

Indonesia is a country with a high potential regarding wildlife diversity (Hanafiah et al., 2018). Moreover, almost $25 \%$ of the world's primate species are found in Indonesia and 24 of them are categorized as endemic primates (Fauzi et al., 2017). The distribution of primate populations in Indonesia is quite wide (Comanesi et al., 2017). Java Island has various endemic primate species, including the Java Gibbon (Hylobates moloch) and Java Lutung (Trachypithecus sp.). Java langur based on differences in hair color are divided into two, namely the West Java langur (Trachypithecus mauritius) and the East Java langur (Trachypithecus auratus) (Brandon-Jones, 1995).

Hunting for wildlife, deforestation, habitat loss due to fragmentation and death caused by disease can also disrupt and affect the stability of primate populations, so efforts are needed to preserve them so that they do not become extinct in the future (Astriani et al., 2015). Animal rehabilitation centers that concentrate on treating primates in Java include the Java
Primate Rehabilitation Center (JPRC) in West Java and the Java Langur Center (JLC) in East Java which organized by The Aspinall Foundation. This conservation program is generally known as The Aspinall Foundation Indonesia Program (Wedana et al., 2013).

Parasitic disease is one of the diseases that can infects Primates. Joesoef et al. (2018) stated that parasitic transmission occurs due to interactions between humans and primates. These interactions can be established in several aspects, such as ecology, work, recreation and research. Kurniawati et al. (2020) stated that non-human primates including Java langur and Java gibbon can become reservoirs and potential hosts for transmitting parasitic diseases that can be found in humans. Huffman et al. (2013) stated that 33 species of zoonotic parasites were detected in humans in Sri Lanka and five species of them, such as Balantidium coli, Plasmodium spp., Sarcocystis sp., Bertiella studeri and Echinococcus granulosus were reported to originate from primates considered as reservoir hosts. 
Individual body condition and health status can also be affected by the presence of ectoparasites and thus affect the health of the population. Klein et al. (2018) stated that high ectoparasite infestation can cause the host to get additional external stressors and have a severe impact on parasite infection. Ectoparasites also need to be watched out for because they have potential as vectors for pathogen transmission. Non-human primates have an important role because they have a phylogenetic closeness to humans, therefore it is very important to increase knowledge about parasites in wildlife.

\section{Materials and Methods}

The samples used in this study were faecal samples from 68 primates. The total number of animals in the JLC is 25 East Java langurs, while the total number of animals in the JPRC is 43 consisting of 19 West Java langurs, 5 East Java langurs and 19 Java gibbons.

Examination of fecal samples was carried out using the native method and the ovatec flotation method to detect gastrointestinal endoparasites such as protozoa and worm eggs, while the examination of ectoparasites followed the schedule of animal medical check-up. The method used for examination of ectoparasites is the mounting method without staining for lice, ticks and fleas. Moreover, if a scab lesion is found, the scraping method is carried out followed by the microscopy method for mite examination.

The observed variables were the presence or absence of gastrointestinal endoparasites and ectoparasites in Java gibbons and Java langurs, then identified. Determination of parasite species using morphological identification keys according to Foreyt (2001), Ash and Orihel (2007), Mey (2010), Bowman (2014), Taylor et al. (2016) and Durden et al. (2020). The data obtained were then analyzed descriptively. Syukran et al (2017) stated that the prevalence rate can be calculated by the following formula:

Prevalence $(\%)=\frac{\text { Number of positive samples }}{\text { Total samples }} \times 100$

\section{Results and Discussion}

The results of the examination of digestive tract endoparasites and ectoparasites in West Java Lutung, East Java Langur and Java Gibbon (Table 1) conducted on 68 primates rehabilitated at JLC and JPRC in February - October 2020 found nematode worm eggs in one East Java Langur. , four West Java langurs and five Java gibbons. Worm eggs were identified as the genus Trichuris, while ectoparasite examination found lice in one West Java Langur and East Java Langur. The tick was identified as the genus Pedicinus. Infestation of ticks, mites and fleas were not found on examination of ectoparasites, and no infection with gastrointestinal protozoa was found on examination of feces. All positive samples only detected for single infestation.

The results of the fecal eamination using native and floating method showed that there was an infection of worm eggs with an oval shape resembling a lemon, coated with egg cell walls and there was a brownish colored embryo inside, and had symmetrical polar plugs on both ends, which indicated Trichuris trichiura species. The worm egg morphology can be seen in Figure 1.

Table 1 Results of examination of gastrointestinal endoparasites and ectoparasites in West Java Langurs, East Java Langurs and Java Gibbons.

\begin{tabular}{|c|c|c|c|c|c|}
\hline No & Primate Species & $\begin{array}{c}\Sigma \\
\text { Sample }\end{array}$ & $\begin{array}{c}\text { Examination } \\
\text { Results }\end{array}$ & $\begin{array}{l}\Sigma \text { Positive } \\
\text { Sample }\end{array}$ & $\begin{array}{c}\text { Prevalence } \\
(\%)\end{array}$ \\
\hline \multirow[t]{2}{*}{1} & West Java Langur & 19 & Trichuris trichiura & 4 & 21,1 \\
\hline & & & Pedicinus ancoratus & 1 & 5,3 \\
\hline \multirow[t]{2}{*}{2} & East Java Langur & 30 & Trichuris trichiura & 1 & 3,3 \\
\hline & & & Pedicinus ancoratus & 1 & 3,3 \\
\hline \multirow[t]{2}{*}{3} & Java Gibbon & 19 & Trichuris trichiura & 5 & 26,3 \\
\hline & & & Pedicinus ancoratus & o & o \\
\hline
\end{tabular}




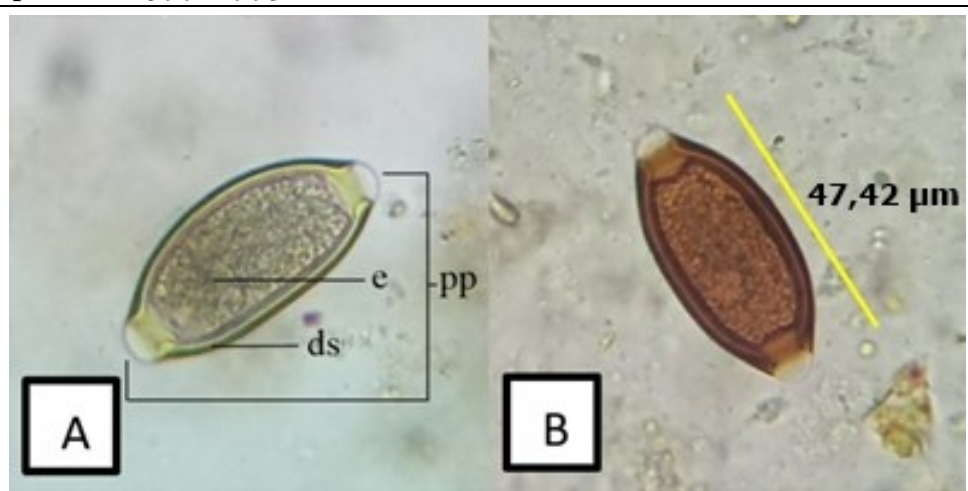

Figure 1. Trichuris trichiura egg based on fecal examinations (A) floatation method and (B) native method, measurement using application NIS-Elements BR 4.10.oo and the length of egg was recorded at $47.42 \mu \mathrm{m}$. Description: $\mathrm{pp}=$ polar plug, $\mathrm{e}=$ embryo, $\mathrm{ds}=$ cell wall. $640 \mathrm{x}$ magnification .

The results of fecal examination showed that there was infection with eggs of Nematode class, namely Trichuris sp., with egg morphology oval in shape, lined with cell walls, brownishcolored embryos, and equipped with symmetrical polar plug formations at both ends. In accordance with previous report by Foreyt (2001). The measurement results showed that Trichuris egg length was $45.44 \mu \mathrm{m}$, in accordance with the key to morphological identification according to Ash and Orihel (2007) which stated that Trichuris trichiura eggs have an egg size of about $50 \mu \mathrm{m}$ while Trichuris vulpis has a much longer egg length, which is about 72-90 $\mu \mathrm{m}$. Taylor et al. (2016) also stated that species from the genus Trichuris (whip worms) that can infect humans and NHP (Nonhuman primates) are Trichuris trichiura species. Rivero et al. (2020) stated that many species of Trichuris can infect humans, but only Trichuris trichiura which for many years has been considered a whipworm that is specific to primates.

In this study, only eggs of the Trichuris trichiura species were found as endoparasite. The results of this study in accordance with the research conducted by Tiwari et al. (2017) on Nilgiri Langurs (Trachypithecus johnii) in India with the highest prevalence of gastrointestinal parasites, namely Trichuris trichiura, but there was a difference such as in this study no other types of gastrointestinal parasites were found, either eggs of other species of worms or protozoa, possibly because the animals were rehabilitated when the medical check-up was already given anthelmintics so that influence the possibility of finding endoparasites. Kurniawati et al. (2020) stated that differences in prevalence and type of infection may depend on the life cycle of the parasite, geographical conditions, food sources, and feeding behavior of primates.

Based on the results in this study, one type of ectoparasite was found, based on the morphology, it was included in the lice group. The results of microscopic examination showed that the ectoparasite samples had a flatdorsoventral body shape, the outer wall of the body was lined with chitin, had a head that had two antennae and three pairs of legs equipped with hooks at the ends. The general body parts consisting of the head, thorax and abdomen can be seen in Figure 2 .

The lice found in this study have a pair of antennae, each antenna has five segments. The thorax has three pairs of locomotion in the form of legs with the tibio-tarsus. The anterior paws have fairly slender claws, while the middle and posterior paws have slightly fatter claws. The abdomen has paratergal plates located in the fourth to sixth segments, the genital plate is located in the posterior part of the abdomen. Based on the results of observations and morphological identification keys according to Mey (2010) and Durden et al. (2020), and based on the host it can be identified that the lice species obtained is Pedicinus ancoratus.

The result of measuring the total body length of Pedicinus ancoratus in this study was $1.030 \mathrm{~mm}$. The head length is $0.300 \mathrm{~mm}$ and the head width is $0.150 \mathrm{~mm}$. The length of the thorax is $0.190 \mathrm{~mm}$ and the width of the thorax is 0.230 $\mathrm{mm}$. Abdominal length 0.540 and abdominal width $0.480 \mathrm{~mm}$, the results of these measurements have differences with research conducted by Durden et al. (2020) the total body length reaches $1.675 \mathrm{~mm}$, the head width is 0.255 $\mathrm{mm}$ and the thorax width is $0.355 \mathrm{~mm}$. This difference may be due to the different species of Pedicinus being measured. 


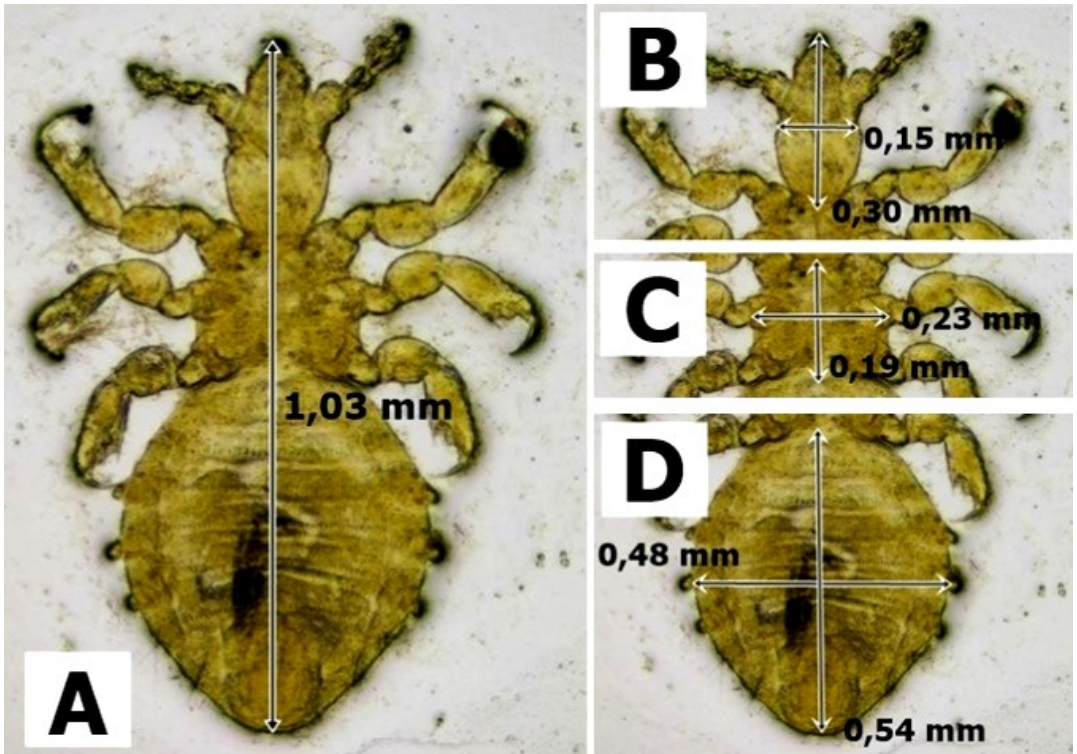

Figure 2. Morphology of Pedicinus ancoratus. (A) general morphology with body length $1.03 \mathrm{~mm}$, consist of $(B)=$ Head, with $0.30 \mathrm{~mm}$ in length $\mathrm{x} 0.15 \mathrm{~mm}$ in width, $(\mathrm{C})=$ Thorax, with $0.23 \mathrm{~mm}$ length $\mathrm{x} 0.19 \mathrm{~mm}$ width and $(\mathrm{D})=$ Abdomen, with $0.54 \mathrm{~mm}$ length $\mathrm{x} 0.48 \mathrm{~mm}$ width. Magnification of $10 \mathrm{x}$ using fluorescence microscope Nikon Eclipse $\mathrm{Ci}$ and measurement using NIS-Elements BR 4.10.oo.

Based on this study, in addition to the adult stage, eggs were also found attached to the body hair of the Javan Langur in the thigh and stomach area. The egg has an operculum, is blackish white and is attached to the hair, this is in accordance with what was said by Taylor et al. (2016). Pedicinus ancoratus eggs can be seen in Figure 3.

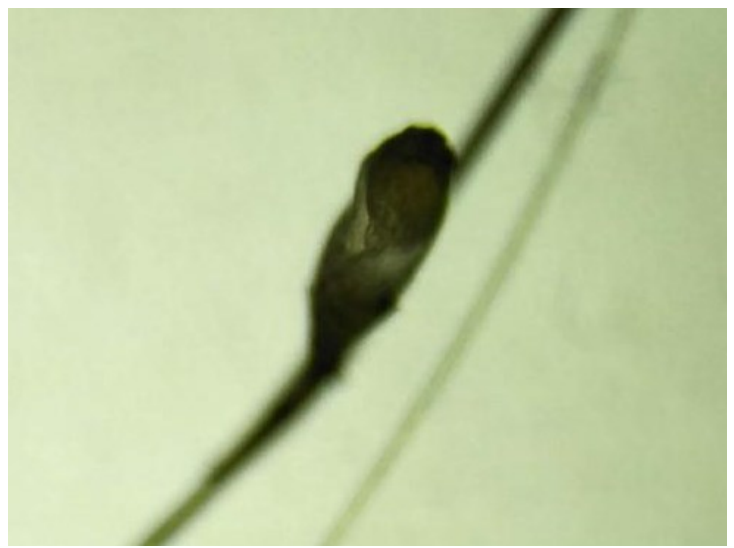

Figure 3. Egg of Pedicinus ancoratus. 40x magnification using a light microscope.

Schol et al. (2012) stated that ticks mostly move between their hosts through direct hostto-host contact and are usually host-specific (can only be transmitted to one host species). Pedicinus ancoratus has only ever been found to infest langur and has never been found in Java gibbons. Based on research conducted by Durden and Musser (1994) and Mey (2010) stated that the infestation of Pedicinus ancoratus was found in Java langur (Trachypithecus auratus and Trachypithecus mauritius), gray langur (Trachypithecus cristatus), Francois langur (Trachypithecus francoisi) and red langur (Presbytis rubicunda).

\section{Conclusion}

The ectoparasites that infest the East Javan langur (Trachypithecus auratus) and West Java langur (Trachypithecus mauritius) were Pedicinus ancoratus, with a prevalence of $3.3 \%$ in East Java langur and $5.3 \%$ in West Java langur, while in the Java gibbon (Hylobates moloch) no ectoparasite infestation was found. Moreover, gastrointestinal endoparasites that found in the East Java langur (Trachypithecus auratus), West Java langur (Trachypithecus mauritius) and Java gibbon (Hylobates moloch) were Trichuris trichiura with a prevalence of 3.3\% in East Java langur, 21.1\% in the West Java langur, and $26.3 \%$. in the Java gibbon respectively.

\section{Acknowledgement}

Thanks to the Aspinall Foundation Indonesia Program as the manager of primate rehabilitation centers in East Java, namely the Java Langur Center and Java Primate Rehabilitation Center in West Java and also all individuals who have helped during the investigation of present study. 


\section{References}

Ash, R. L. and T. C. Orihel. 2007. Atlas of Human Parasitology. Chicago: American Society for Clinical Pathology. Hal. 50, 58, 84, 97 - 186.

Astriani, W. I., H. Arief dan L. B. Prasetyo. 2015. Populasi dan Habitat Lutung Jawa (Trachypitecus auratus E. Geoffrey 1812) di Resort Balanan, Taman Nasional Baluran. J. Media Kons 20(3): 226-234

Brandon-Jones D. 1995. A revision of the Asian pied leaf-monkeys (Mammalia: Cercopithecidae: superspecies Semnopithecus auratus), with a description of a new subspecies. Raffles Bulletin of Zoology. 43: 3-43.

Bowman, D. D. 2014. Georgis' Parasitology for Veterinarians $10^{\text {th }} \quad$ Edition.St. Louis, Missouri: Elsevier Saunders. Hal. 52, 122 156

Comanesi, Y. D., Erianto dan S. Rifanjani. 2017. Keanekaragaman Jenis Primata Diurnal di dalam Areal IUPHHK-HT PT. Bina Silva Nusa Kecamatan Batu Ampar Kabupaten Kubu Raya Provinsi Kalimantan Barat. J. Hutan Lestari. 5(2): 563-570.

Durden, L.A., S. E. Kessler, L. Boundenga, B. Ngoubangoye, T. A. Tsoumbou, C. I. Mousadji-Kinga, M. Halbwax, J. M. Setchell, J. Nicholas and S. E. Greiman. 2020. A New Species of Sucking Louse from the Madrill from Gabon with a Review of Host Associations and Geographical Distributions and Identification Keys to Members of the Genus Pedicinus (Phthiraptera: Anoplura: Pedicinidae). Journal of Parasitology. 106(2) : 221-232.

Durden, L.A and G. G. Musser. 1994. The Sucking Lice (Insecta, Anoplura) of the World: a Taxonomic Checklist with Records of Mammalian Hosts and Geographic Distributions. Bulletin of the American Museum of Natural History. 218: 1-90.

Fauzi, F., R. Rahmawati dan P. Sandan. 2017. Estimation of Population Density and Food Sort of Kelasi (Presbytis rubicunda Muller 1838) in Nyaru Menteng Arboretum of Palangka Raya. J. Daun. 4(1):7-16.

Foreyt, W.J. 2001. Veterinary Parasitology Reference Manual, $5^{\text {th }}$ ed. Ames Iowa (US): Iowa State University Press. 181-197.
Hanafiah, M., H. D. Alfiansyah dan A. Sayuti. 2018. Identifikasi Parasit pada Biawak Air (Varanus salvator). Jurnal Sains Veteriner. 36(1): 24-31.

Huffman, M. A., C. A. D. Nahallage, H. Hasegawa, S. Ekanayake, L. D. G. G. De Silva and I. R. K. Athauda. 2013. Preliminary Survey of the Distribution of Four Potentially Zoonotic Parasite Species Among Parasites in Sri Lanka. Journal National Science Foundation Sri Lanka. 41(4): 319-326.

Joesoef, J. A., D. Sajuthi, A. Wijaya, M. U. E. Sanam. 2018. Keragaman Endoparasit pada Macaca fascicularis dan Potensi Zoonotiknya dengan Cuaca Berbeda di Kota Kupang. Jurnal Veteriner. 19(4): 451-459.

Klein, A., E. Zimmermann, U. Radespiel. G. Schaarschmidt. A. Springer and C. Strube. 2018. Ectoparasite communities of smallbodied Malagasy primates: seasonal and socioecological influences on tick, mite and lice infestation of Microcebus murinus and M. ravelobensis in northwestern. Journal Parasites and Vectors. 11(459): 1-18.

Kurniawati, D.A., L. T. Suwanti, N. D. R. Lastuti, S. Koesdarto, E. Suprihati, M. Mufasirin dan A. Pratiwi. 2020. Zoonotic potential of gastrointestinal parasite in long-tailed Macaque Macaca fascicularis at Baluran National Park, Situbondo, East Java, Indonesia. Aceh Journal of Animal Science. 5(1): 47-56.

Mey, Eberhard. 2010. The Pedicinus Species (Insecta, Pthiraptera, Anoplura, Pedicinidae) on Douc Langurs (Pygathrix spp.). Vietnamese Journal of Primatology. 4(1): 57-68.

Rivero, J., A. M. Garcia-Sanchez, A. Zurita, C. Cutillas and R. Callejon. 2020. Trichuris trichiura isolated from Macaca sylvanus: morphological, biometrical, and molecular study. BMC Veterinary Research. 16(445): 14

Scholl, K., M. A. Julie, H. L. Fabian, A. C. Colin and L. R. David. 2012. Variable Microsatellite Loci for Population Genetic Analysis of Old World Monkey Lice (Pedicinus sp.). Journal Parasitology. 98(5): 930-937. 
Taylor, M. A., R. L. Coop and R. L. Wall. 2016. Veterinary Parasitology. $4^{\text {th }}$ Edition. Blackwell Publishing. UK. 853-886.

Tiwari, S., D. M. Reddy, M. Pradheeps., G. S. Sreenivasamurthy and G. Umapathy. 2017. Prevalence and co-occurrence of gastrointestinal parasites in Nilgiri Langur (Trachypithecus johnii) of fragmented landscape in Anamalai Hills, Western Ghats, India. Current Science. 113(10): 21942200.
Wedana, M., I. Kurniawan, Z. Arsan, N. B. Wawandono, A. Courage and T. King. 2013. Reinforcing the Isolated Javan Langur Population in the Coban Talun Protected Forest, East Java, Indonesia. Wild Conservation. 1(5): 31-39. 